\title{
RELASI JENDER DALAM NOVEL CINTA DI DALAM GELAS KARYA ANDREA HIRATA
}

\author{
Erni Susilawati $^{1}$, Novia Winda ${ }^{2}$, Adi Purwanto ${ }^{3}$ \\ ${ }^{1), 2}$ Pendidikan Bahasa dan Sastra Indonesia \\ STKIP PGRI Banjarmasin \\ Jalan Sultan Adam, Komplek H. Iyus, No. 18 RT.23 Banjarmasin, \\ Kalimantan Selatan. Kode pos 70121 \\ email: ernisusilawati1975@gmail.com

\section{${ }^{3)}$ Alumni Pendidikan Bahasa dan Sastra Indonesia STKIP PGRI Banjarmasin} \\ Jalan Sultan Adam, Komplek H. Iyus, No. 18 RT.23 Banjarmasin, \\ Kalimantan Selatan. Kode pos 70121
}

\begin{abstract}
ABSTRAK
Relasi jender dibentuk dari tradisi, sosial dan budaya, yakni hubungan antara laki-laki da perempuan. Namun dalam pembagian tugas dan fungsi jender sering menimbulkan ketidakadilan bagi perempuan. Ketidakadilan ini terkadang tidak disadari atau diterima sebagai suatu ketetapan oleh kaum perempuan itu sendiri. Novel Cinta dalam gelas menggambarkan suatu budaya dimasyarakat yang sangat kental dengan diskriminasi terhadap kaum perempuan. Parahnya lagi ketidakadilan itu dianggap sudah tradisi yang bersumber dari budaya dan agama. Hingga munculah seorang tokoh yang mencoba mendobrak tradisi yang sudah melekat secara kuat dimasyarakat mengenai relasi atau peran laki-laki dan perempuan dan membuktikan bahwa seorang perempuan mampu mengerjakan pekerjaan yang dianggap haknya laki-laki.
\end{abstract}

Kata Kunci: Relasi Jender, Novel

\section{PENDAHULUAN}

Karya sastra sebagai media bagi jiwa seorang pengarang yang merasa mempunyai tugas untuk memberikan andil sebagai penyampai nilai-nilai kebaikan dalam kehidupan manusia di muka bumi ini. Seorang pengarang dianggap berhasil apabila mampu membawakan nilai-nilai kebaikan dalam kehidupan melalui karya sastra yang dia tulis, sehingga pembaca tidak merasa digurui atau diceramahi namun tanpa disadari pesan atau nilai kebaikan dalam karya sastra dapat diterima dengan baik.

Novel adalah salah satu bentuk karya sastra tulis yang banyak diminati oleh pembaca karena alur cerita yang lengkap. Masalah umum yang juga dimuat di dalam novel adalah masalah jender. Jender adalah sifat serta peran yang melekat pada laki-laki dan perempuan secara sosial maupun kultural. Dalam kehidupan sehari-hari sering terjadi ketimpangan jender, contohnya adalah kekerasan yang sering terjadi pada orang yang dianggap lemah, dalam hal ini adalah wanita, pelecehan seksualdan lain sebagainya. Berbagai bentuk ketimpangan jender itu kemudian dapat dijumpai di dalam karya sastra yang berbentuk fiksi yang hasilnya berupa puisi, prosa,dan drama. 
Permasalahan yang muncul dari perspektif jender lebih difokuskan pada aspek sosial yang melihat perbedaan jenis kelamin manusia dalam kedudukannya ditengah masyarakat. Permasalahan tersebut tidak akan terjadi jika ada keadilan dan kesetaraan hubungan antara laki-laki dan perempuan dalam ruang pergaulan sosial yang saling menghargai, berperikemanusiaan, dan mengedepankan kesepahaman satu sama lain. Fakta membuktikan bahwa makhluk yang sering mengalami bentuk ketidakadilan adalah perempuan. Perempuan selalu menjadi sosok nomor dua dalam pergaulan sosial dan hal itu telah berlangsung lama. Hal tersebut membangkitkan kesadaran bagi kaum perempuan untuk melakukan usaha-usaha demi tercapainya kesetaraan jender.

Novel yang berjudul Cinta dalam Gelas karya Andre Hirata adalah salah satu dari sekian banyak karya sastra yang mencoba memberikan gambaran mengenai ketidakadilan akibat perbedaan jender. Namun karya Hirata ini ditulis dengan cerita yang menarik dan alur cerita yang tidak membosankan. Dalam novel Cinta dalam Gelas menceritakan tentang perjuangan hidup seorang perempuan yang bernama Maryamah atau lebih dikenal dengan panggilan Enong. Perjuangan hidup yang dihadapi Enong lebih beralaskan pada faktor ekonomi dan marginalisasi perempuan yang terjadi di sebuah kampung di Belitung. Enong ingin membuktikan bahwa perempuan tidaklah selemah yang dilihat, perempuan mampu mengemban tugas sebagai kepala keluarga sekaligus sebagai seorang anak dan kaka yang bertanggungjawab. Perempuan yang lembut namun keras dalam menghadapi hidup ini juga memendam amarah pada orang yang telah menyakitinya dengan mengalahkannya pada kejuaraan catur di even 17 agustusan.

Berdasarkan latar belakang masalah diatas, peneliti tertarik untuk mengadakan penelitian yang berjudul "Relasi JenderDalam Novel Cinta di Dalam Gelas Karya Andrea Hirata".Salah satu novel karya Andrea Hirata yang berjudul "Cinta di Dalam Gelas" dianggap cocok untuk dijadikan objek analisis jender. Novel tersebut dipilih sebagai objek penelitian karena isi novel tersebut banyak mengandung masalah yakni bentuk ketidakadilan jender.

\section{METODE}

Adapun pendekatan yang digunakan dalam penelitian ini adalah pendekatan sosiologi.Endraswara (2013:79) mengungkapkan bahwa sosiologi sastra adalah penelitian yang terfokus pada masalah manusia.Kareana sastra sering mengungkapkan perjuangan umat manusia dalam menentukan masa depannya, berdasarkan imajinasi, perasaan, dan intuisi.

Dalam sebuah penelitian, penentuan sebuah metode sangat diperlukan agar proses kerja dapat dilaksanakan secara sistematis dan terarah sehingga tujuan penelitian dapat tercapai. Metode yang digunakan dalam penelitian ini adalah deskriptif analisis. Ratna (2011:53) mengungkapkan bahwa deskriptif analisis dilakukan dengan cara mendeskripsikan fakta-fakta yang kemudian disusul dengan analisis. 
Teknik analisis data merupakan bagian yang penting dalam sebuah penelitian karena dengan analisis data yang diteliti akan dapat diketahui makna atau jawaban pemecahan masalahnya.Endraswara (2013:161) mengungkapkan bahwa analisis konten adalah strategi untuk menangkap pesan karya sastra.Teknik analisis data yang digunakan dalam penelitian ini adalah teknik analisis konten.

\section{HASIL DAN PEMBAHASAN}

\section{Jender}

Untuk memahami konsep jender harus dibedakan kata jender dengan kata seks (jenis kelamin).Pengertian jenis kelamin merupakan pensifatan atau pembagian dua jenis kelamin manusia yang ditentukan secara biologis yang melekat pada jenis kelamin tertentu. Misalnya, bahwa manusia jenis laki-laki adalah manusia yang memiliki atau bersifat seperti daftar berikut ini: laki-laki adalah manusia yang memiliki penis, memiliki jakala (kala menjing) dan memproduksi sperma. Sedangkan perempuan memiliki alat reproduksi seperti rahim dan saluran untuk melahirkan, memproduksi telur, memiliki vagina, dan mempunyai alat menyusui.Alat-alat tersebut secara biologis melekat pada manusia jenis perempuan dan laki-laki selamanya.Artinya secara biologis alat-alat tersebut tidak bisa dipertukarkan antara alat biologis yang melekat pada manusia laki-laki dan perempuan.Secara permanen tidak berubah dan merupakan ketentuan biologis atau sering dikatakan ketentuan Tuhan atau kodrat.

Sedangkan konsep lainnya adalah konsep jender, yakni suatu sifat yang melekat pada kaum laki-laki maupun perempuan yang dikonstruksi secara sosial maupun kultural.Misalnya, bahwa perempuan itu dikenal lemah lembut, cantik, emosional, atau keibuan.Sementara laki-laki dianggap kuat, rasional, jantan, perkasa.

\section{Relasi Jender}

Relasi Jender (Jender Relation) adalah relasi kuasa yang hirarkis antara antara laki-laki dan perempuan dan merupakan relasi kuasa yang cenderung merugikan perempuan (Reeves and Baden, 2000 dalam Online).Relasi jender terjadi secara simultan yang ditandai dengan kerjasama, ketertautan, saling mendukung, dan konflik, perpisahan, dan persaingan yang terjadi karena perbedaan dan ketidaksetaraan.Relasi jender berkaitan dengan bagaimana kuasa (power) didistribusikan diantara kedua jenis kelamin tersebut.

Relasi jender yang hirarkis seringkali dianggap sebagai relasi yang "normal", namun relasi tersebut dibentuk secara sosial dan budaya dan bisa berubah dari waktu ke waktu. Relasi jender dapat dikategorikan sebagai praktek jender seperti dalam pembagian kerja dan sumberdaya, dan ideologi jender seperti pandangan tentang perilaku mana yang pantas bagi laki-laki dan 
perempuan.Kelompok relasi jender memberi penekanan kuat pada keterhubungan hidup laki-laki dan perempuan dan ketidakseimbangan kuasa yang melekat pada relasi laki-laki-perempuan.Mereka juga menekankan interaksi relasi jender dengan relasi sosial yang hirarkis lainnya seperti kelas, kasta, etnisitas dan ras.

Banyak budaya yang menganggap pemukulan dan perkosaan dalam perkawinan sebagai hal yang biasa dan bisa diterima dalam sistem hukum setempat. Atau, meskipun perkosaan dan kekerasan sudah diatur dalam sistem hukum, perempuan masih enggan untuk melaporkan karena sikap tak simpatik dari sistim hukum yang didominasi oleh kaum pria, atau oleh karena mereka kuatir akan ditinggalkan, diceraikan, dan sebagainya.

\section{Ketidakadilan jender}

Ketidakadilan jender merupakan sistem dan struktur di mana baik kaum laki-laki dan perempuan menjadi korban dari sistem tersebut.Untuk memahami bagaimana perbedaan jender menyebabkan ketidakadilan jender, dapat dilihat melalui pelbagai manifestasi dalam pelbagai bentuk ketidakadilan yang ada. Ketidakadilan jender termanifestasikan dalam pelbagai bentuk ketidakadilan, yakni: Marginalisasi atau proses pemiskinan ekonomi, subordinasi atau tanggapan tidak penting dalam keputusan politik, pembentukan stereotipe atau melalui pelabelan negatif, kekerasan (violence), beban kerja lebih panjang dan lebih banyak (burden), serta sosialisasi ideologi nilai peran jender. Manifestasi ketidakadilan jender ini tidak dapat dipisah-pisahkan, karena saling berkaitan dan berhubungan, sailing mempengaruhi secara dialeksis. Tidak ada satupun dialeksis. Tidak ada satupun manifestasi ketidakadilan jender yang lebih penting, lebih esensial, dari yang lain. Misalnya, marginalisasi ekonomi kaum perempuan justru terjadi karena stereotipe tertentu atas kaum perempuan dan itu menyumbang kepada subordinasi, kekerasan kepada kaum perempuan, yang akhirnya tersosialisasikan dalam keyakinan, ideologi dan visi kaum perempuan sendiri. Dengan demikian, kita bisa menyatakan bahwa marginalisasi kaum perempuan adalah menentukan dan terpenting dari yang lain dan oleh karena itu perlu mendapat perhatian lebih. Atau sebaliknya, bahwa kekerasan fisik (violence) adalah masalah paling mendasar yang harus dipecahkan terlebih dahulu.

1) Jender dan Marginalisasi Perempuan

Proses marginalisasi, yang menyebabkan kemiskinan, sesungguhnya banyak sekali terjadi dalam masyarakat dan Negara yang menimpa kaum laki-laki dan perempuan, yang disebabkan oleh berbagai kajadian, misalnya penggusuran, bencana alam atau proses eksploitasi.Namun ada salah satu bentuk pemiskinan atas satu jenis kelamin tertentu, dalam hal ini perempuan, disebabkan oleh jender. Ada beberapa perbedaan jenis dan bentuk, tempat dan waktu serta mekanisme proses marginalisasi kaum perempuan karena perbedaan jender tersebut. Dari segi 
sumbernya bisa berasal dari kebijakan pemerintah, keyakinan, tafsir agama, keyakinan tradisi dan kebiasaan atau bahkan asumsi ilmu pengetahuan.

(Fakih. 1999:15) mengemukakan bahwa Marginalisasi perempuan tidak hanya terjadi di tempat pekerjaan, juga terjadi dalam rumah tangga, masyarakat atau kultur dan bahkan Negara. Marginalisasi terhadap perempuan sudah terjadi sejak di rumah tangga dalam bentuk diskriminasi atas anggota keluarga yang lai-laki dan perempuan. Marginalisasi juga diperkuat dengan adat istiadat maupun tafsir keagamaan, misalnya banyak diantara suku-suku di Indonesia yang tidak memberi hak kepada perempuan untuk mendapatkan waris sama sekali. Sebagai tafsir keagamaan memberi hak waris setengah dari hak waris kali-laki terhadap kaum perempuan.

2) Jender dan subordinasi

Pandangan jender ternyata bisa menimbulkan subordinasi terhadap perempuan.Anggapan bahwa perempuan itu irrasional atau emosional sehingga perempuan tidak bisa tampil memimpin, berakibat munculnya sikap yang menempatkan perempuan pada posisi yang tidak penting.

3) Jender dan stereotipe

Fakih.(1999:16) mengemukakan bahwa secara umum stereotipe adalah pelabelan atau penandaan terhadap suatu kelompok tertentu.Celakanya stereotipe selalu merugikan dan menimbulkan ketidakadilan.Stereotipe yang diberikan kepada suku bangsa tertentu, misalnya Yahudi di Barat, Cina di Asia Tenggara, telah merugikan suku bangsa tersebut.Salah satu jenis stereotipe itu adalah yang bersumber dari pandangan jender.Banyak sekali ketidakadilan terhadap jenis kelamin tertentu, umumnya perempuan, yang bersumber dari penandaan (stereotipe) yang dilekatkan pada mereka.Misalnya, penandaan yang berawal dari asumsi bahwa perempuan bersolek adalah dalam rangka memancing perhatian lawan jenisnya, maka setiap ada kasus kekerasan atau pelecehan seksual selalu dikaitkan dengan stereotipe ini.Bahkan jika ada pemerkosaan yang dialami oleh perempuan, masyarakat berkecenderungan menyalahkan korbannya.

Masyarakat memiliki anggapan bahwa tugas utama kaum perempuan adalah melayani suami.Stereotipe ini berakibat wajar sekali jika pendidikan kaum perempuan dinomorduakan.Stereotipe terhadap kaum perempuan ini terjadi di mana-mana. Banyak peraturan pemerintah, aturan keagamaan, kultur dan kebiasaan masyarakat yang dikembangkan karena stereotipe tersebut.

4) Jender dan kekerasan

Kekerasan (violence) adalah serangan terhadap fisik maupun integritas mental psikologis seseorang.(Fakih.1999:17) mengemukakan bahwa kekerasan terhadap kaum manusia pada 
dasarnya berasal dari berbagai sumber, namun salah satu kekerasan terhadap satu jenis kelamin tertentu yang disebabkan oleh anggapan jender. Kekerasan yang disebabkan oleh bias jender ini disebut jender-relate violence.Pada dasarnya, kekerasan jender disebabkan oleh ketidaksetaraan kekuatan yang ada dalam masyarakat. Banyak macam dan bentuk kejahatan yang bisa dikategorikan sebagai kekerasan jender, diantaranya:

Pertama, bentuk pemerkosaan terhadap perempuan, termasuk perkosaan dalam perkawinan.Perkosaaan terjadi jika seseorang melakukan paksaan untuk mendapatkan pelayanan seksual tanpa kerelaan yang bersangkutan.

Kedua, tindakan pemukulan dan serangan fisik yang terjadi dalam rumah tangga (domestic violence).Termasuk tindak kekerasan dalam bentuk penyiksaan terhadap anak-anak.

Ketiga, bentuk penyiksaan yang mengarah kepada organ alat kelamin (genital mutilation), misalnya penyunatan terhadap anak perempuan.

Keempat, kekerasan dalam bentuk pelacuran (prostitution).Pelacuran merupakan bentuk kekerasan terhadap perempuan yang diselenggarakan oleh suatu mekanisme ekonomi yang merugikan kaum perempuan.

Kelima, kekerasan dalam bentuk pornografi.Kekerasan ini termasuk kekerasan nonfisik, yakni pelecehan terhadap kaum perempuan dimana tubuh perempuan dijadikan objek demi keuntungan seseorang.

Keenam, kekerasan dalam bentuk pemaksaan sterilisasi dalam Keluarga Berencana (enforced sterilization).Keluarga Berencana dibanyak tempat ternyata telah menjadi sumber kekerasan terhadap perempuan.

Ketujuh, adalah jenis kekerasan terselubung (molestation), yakni memegang atau menyentuh bagian tertentu dari tubuh perempuan dengan pelbagai cara dan kesembatan tanpa kerelaan si pemilik tubuh.

Kedelapan, tindakan kejahatan terhadap perempuan yang paling umum dilakukan di masyarakat yakni yang dikenal dengan pelecehan seksual. Jender dan Beban Kerja

Fakih.(1999:21) mengemukakan bahwa bias jender yang mengakibatkan beban kerja seringkali diperkuat dan disebabkan oleh adanya pandangan atau keyakinan di masyarakat bahwa pekerjaan yang dianggap masyarakat sebagai jenis "pekerjaan perempuan", seperti semua pekerjaan domestik, dianggap dan dinilai lebih rendah dibandingkan dengan jenis pekerjaan yang dianggap sebagai "pekerjaan laki-laki", serta dikategorikan sebagai "bukan produktif" sehingga tidak diperhitungkan dalam statistik ekonomi Negara. Sementara itu kaum perempuan, karena angapan jender ini, sejak dini telah disosialisasikan untuk menekuni peran jender mereka. Di lain pihak kaum lelaki tidak diwajibkan secara kultural untuk menekuni 
berbagai jenis pekerjaan domestik itu. Kesemuanya ini telah memperkuat pelanggengan secara kultural dan struktural beban kerja kaum perempuan.

\section{Faktor yang Mempengaruhi Ketidakadilan Jender}

Ketidakadilan dan diskriminasi terhadap perempuan, disebabkan oleh banyak faktor. Menurut (Masdar F. Mas'udi dalam Online), pangkal mulanya adalah disebabkan adanya pelebelan sifat-sifat tertentu (streotype) pada kaum perempuan yang cenderung merendahkan. Misalnya, bahwa perempuan itu lemah, lebih emosional ketimbang nalar, cengeng, tidak tahan banting, tidak patut hidup selain di dalam rumah, dan sebagainya. Berdasarkan pelebelan sifat-sifat manusia kelas dua inilah ketidakadilan terjadi atas mereka. Ada empat persoalan yang menimpa perempuan akibat dari adanya pelebelan ini, yaitu:

1) Melalui proses subordinasi. Yaitu meletakkan perempuan di bawah supremasi lelaki, perempuan harus tunduk kepada sesama manusia, yakni kaum lelaki. Pemimpin atau imam hanya pantas dipegang oleh lelaki; perempuan hanya boleh menjadi makmum saja.

2) Adanya marginalisasi perempuan. Yaitu perempuan cenderung dimarginalkan, yaitu diletakkan di pinggir. Dalam rumah tangga perempuan adalah konco wingking di dapur. Dalam kegiatan masyarakat, perempuan paling tingg hanya menjadi seksi konsumsi atau penerima tamu. Mungkin karena posisinya yang dianggap tidak penting ini, maka pendidikan untuk kalangan perempuan pada umumnya seperlunya saja.

3) Perempuan berada di posisi yang lemah, karenanya perempuan sering menjadi sasaran tindak kekerasan (violence) oleh kaum laki-laki. Bentuk kekerasan itu mulai dari digoda, dilecehkan, dipukul atau dicerai.

Akibat ketidakadilan jender itu perempuan harus menerima beban pekerjaan yang lebih jauh lebih berat dan lebih lama dari pada yang dipikul kaum lelaki. Lelaki yang paling aktif maksimal bekerja rata-rata 10 jam/hari. Sedangkan perempuan bekerja 18 jam/hari. Beban ini pada umumnya dianggap remeh oleh lelaki, karena secara ekonomi dinilai kurang berarti.

Novel yang berjudul Cinta dalam Gelas karya Andre Hirata ini menceritakan kisah hidup seorang perempuan yang bernama Maryamah atau yang lebih dikenal dengan panggilan Enong.Enong merupakan seorang perempuan pendulang timah, yang berjuang untuk ibu dan tiga adik perempuannya.Karena perjuangan dan pengorbannya terkadang Enong tidak mempedulikan kehidupannya sendiri, Hingga pada akhirnya ia memutuskan untuk menikah dengan lelaki bernama Tarom. Namun dalam pernikahan Enong tidak bahagia karena ternyata suaminya adalah seorang yang telah berkeluarga. Selain itu suaminya adalah juga orang yang suka melakukan kekerasan dalam rumah tangga. Enong akhirnya memutuskan untuk mengakhiri biduk rumah tangganya 
dengan Matarom. Dari sinilah tokoh Enong menyadari betapa keras kehidupan ini, untuk itu harus diperjuangkan dengan sekuat tenaga.

Enong kembali menata hidupnya dengan ia terus mengembangkan diri dengan membekali diri dengan kursus bahasa Inggris dan terus menekuni profesinya sebagai seorang pendulang Intan. Namun bagaimanapun enong masih memiliki dendan pada mantan suaminya Matarom. Ia memendam hastrat untuk bisa mengalahkan matarom pada pertandingan bergensi yakni kejuaraan catur pada 17 asgustus, dimana permainan ini bagi penduduk belitung adalah permainan yang sangat maskulin, yakni hanya dimainkan oleh laki-laki. Walaupun disangsikan dari berbagai kalangan, dan perjuangan yang tidak mudah akhirnya Enong bisa membuktikan bahwa iya layak diperhitungkan dalam permainan tersebut.

\section{Hubungan Jender Dalam Novel CDG Karya Andrea Hirata}

Hubungan jender dalam novel $C D G$ karya Andrea Hirata terdiri dari perbedaan sifat antara laki-laki dan perempuan dalam peran, fungsi, hak, tanggung jawab, dan perilaku yang dibentuk oleh tata nilai sosial, budaya, dan adat istiadat dari kelompok masyarakat.

Jender yakni suatu sifat yang melekat pada kaum laki-laki maupun perempuan yang dikonstruksi secara sosial maupun kultural.Misalnya, bahwa perempuan itu dikenal lemah lembut, cantik, emosional, dan keibuan.Sementara laki-laki dianggap kuat, rasional, jantan, dan perkasa.

Jender yang dimaksud dalam penelitian ini adalah perbedaan sifat antara laki-laki dan perempuan dalam peran, fungsi, hak, tanggung jawab, dan perilaku yang dibentuk oleh tata nilai sosial, budaya, dan adat istiadat dari kelompok masyarakat yang dapat berubah menurut waktu serta kondisi setempat. Seperti halnya dalam novel $C D G$ karya Andrea Hirata terdapat beberapa hubungan jender.Hal tersebut dapat dilihat dari kutipan dibawah ini.

\footnotetext{
Semuanya karena sepanjang hidup ketiga gadis kecil kakak-beradik itu telah menyaksikan bagaimana ibu dan Enong berjuang untuk mereka.Enong bekerja keras menjadi pendulang timah sejak usianya baru 14 tahun.Ia berusaha sedapat-dapatnya memenuhi apa yang diperlukan ketiga adiknya dari seorang ayah. Dibelikannya mereka baju Lebaran, diurusnya jika sakit, dan ia menangis setiap kali mengambil rapor adik-adiknya. Sebab, menandatangani rapor yang seharusnya ditandatangani ayahnya itu, ia rindu pada ayahnya (CDG/AH, 2016:11).
}

Berdasarkan kutipan di atas, Enong telah bekerja keras menjadi pendulang timah sejak berumur 14 tahun.Ia berusaha memenuhi segala apa yang diperlukan oleh adiknya. Bahkan ketika tiba saat mengambil rapor ia juga yang datang menggantikan posisi ayahnya yang telah meninggal. Dapat dilihat tokoh Enong mampu menjalankan pekerjaan yang bersifat maskulin dimana pekerjaan mendulang kebanyakan dilakukan oleh para pria.

Ia adalah lelaki yang baik dengan cinta yang baik. Jika kami duduk di beranda, ayahmu mengambil antip dan memotong kuku-kukuku. Cinta seperti itu akan dibawa perempuan 
sampai mati. Syalimah seperti tak sanggup melanjutkan ceritanya. "jika kuseduhkan kopi, ayahmu menghirupnya pelan-pelan lalu tersenyum padaku." Meski tak terkatakan, anaknya tahu bahwa senyum itu adalah ucapan saling berterima kasih antara ayah dan ibu mereka untuk kasih sayang yang balas-membalas, dan kopi itu adalah cinta di dalam gelas (CDG/AH, 2016:13).

Penggalan cerita di atas, menggambarkan hubungan antara suami yang mewakili sisi maskulinitas dan istri yang mewakili unsur feminitas. Suami yang bekerja dan istri yang menyediakan makanan di rumah. Hubungan yang mereka jalin adalah hubungan saling membutuhkan satu dengan yang lainnya hingga terjalin kasih sayang diantara mereka.

\section{Bentuk-bentuk Ketidakadilan Jender dalam Novel CDG Karya Andrea Hirata}

Ketidakadilan jender merupakan sistem dan struktur dimana baik kaum laki-laki dan perempuan menjadi korban dari sistem tersebut. Untuk memahami bagaimana perbedaan jender menyebabkan ketidakadilan jender, dapat dilihat melalui pelbagai manifestasi dalam pelbagai bentuk ketidakadilan, yakni: marginalisasi terhadap perempuan, subordinasi, stereotip, kekerasan terhadap perempuan, dan beban kerja.

a. Marginalisasi(peminggiran terhadap perempuan yang menyebabkan kemiskinan)

Marginalisasi perempuan tidak saja terjadi di tempat pekerjaan, juga terjadi dalam rumah tangga, masyarakat atau kultur dan bahkan negara. Marginalisasi terhadap perempuan sudah terjadi sejak di rumah tangga dalam bentuk diskriminasi atas anggota keluarga yang laki-laki dan perempuan.Marginalisasi juga diperkuat oleh adat istiadat maupun tafsir keagamaan.Seperti tokoh utama perempuan yang terdapat dalam novel $C D G$ karya Andrea Hirata.Hal tersebut dapat digambarkan pada kutipan berikut. Kutipan 9 "Enong tetap bekerja sebagai pendulang timah. Namun, ia tak lagi satu-satunya perempuan. Sekarang dengan mudah dapat ditemukan perempuan di ladang tambang.Enonglah yang memulai semua itu" (CDG/AH, 2016:18).Dari kutipan di atas, terlihat bahwa Maryamah atau yang sering dipanggil Enong, bekerja keras sebagai pendulang timah.Bahkan, sekarang banyak perempuan-perempuan yang bekerja sebagai pendulang timah.Maryamah adalah perempuan pertama yang bekerja sebagai pendulang timah, karena keterbatasan Maryamah untuk mendapat pekerjaan yang lebih layak. Satu-satunya pekerjaan yang bisa ia lakukan adalah sebagai pendulang timah, untuk mencukupi kebutuhan keluarganya.

Maryamah hingga saat ini masih bekerja sebagai pendulang timah dan sekarang banyak perempuan lain yang mulai mengikuti jejaknya......Perseteruan di warung kopi tak kunjung berhenti. Maryamah dianggap tidak pantas bermain catur karena hanya seorang pendulang timah yang bodoh.....Lelaki di kampung Melayu menyudutkan Maryamah, bahwa permainan catur adalah permainan orang pintar dan orang kantoran saja.

Jadi, marginalisasi terhadap perempuan adalah diskriminasi yang dilakukan karena lelaki menganggap perempuan itu tidak layak untuk bekerja dan melawan lelaki apalagi menyamakan haknya seperti laki-laki. Perempuan itu hanya makhluk lemah di bawah laki-laki dan tidak sepandai 
laki-laki.Apalagi bermain catur yang menggunakan otak, maka Maryamah diremehkan. Maryamah dianggap sebagai orang yang tidak pantas bermain catur, karena dia perempuan.

b. Subordinasi (perempuan dianggap lemah dan cengeng sehingga selalu dinomorduakan setelah laki-laki)

Adanya fenomena budaya telah menjadikan perempuan sebagai kelompok tersendiri dalam masyarakat yang menimbulkan konflik dan ras, khususnya ketidakadilan jender. Subordinasi karena jender tersebut terjadi dalam segala macam bentuk yang berada dari tempat ke tempat dan dari waktu ke waktu.Salah satu bentuk ketidakadilan jender yang sering menimbulkan konflik terhadap perempuan adalah subordinasi.Anggapan bahwa perempuan itu irrasional atau emosional sehingga perempuan tidak bisa tampil memimpin, berakibat munculnya sikap yang menempatkan pada posisi tidak penting.Perempuan sering dianggap sebagai warga kelas kedua sehingga peran mereka tidak pernah dianggap.Perempuan di dalam kehidupan masyarakat selalu tidak dikaitkan dalam masalah publik, mereka tidak pernah dianggap dan disingkirkan.Hal tersebut dapat dilihat pada kutipan di bawah ini.

Percencokan di warung kopi semakin sengit.Perempuan tidak berhak melawan laki-laki. Hak perempuan dan laki-laki berbeda karena laki-laki lebih berhak atas perempuan...Paman berpendapat bahwa catur adalah permaianan laki-laki dan hak laki-laki. Perempuan cocoknya bermain bekel buah siput.....Penonton berulang kali mengejek Maryamah agar meletakkan pedangnya di tanah, namun perempuan itu bertekad untuk membela kehormatannya sampai titik darah penghabisan

Penggalam cerita di atas terlihat bahwa peran perempuan tidak penting. Sebagai kodratnya perempuan dianggap tidak mempunyai hak seperti laki-laki.Banyak yang menentang Maryamah, karena menganggap bahwa perempuan yang berani melawan bertanding catur dengan laki-laki itu adalah perempuan yang tidak mempunyai rasa hormat terhadap laki-laki.Lelaki dianggap lebih berhak atas semuanya dibandingkan perempuan yang selalu di bawah laki-laki.

Permainan catur adalah permaianan laki-laki dan perempuan tidak berhak akan itu. Menurut pandangan orang Melayu jaman dulu, seorang perempuan hanya cocok bermain permaianan anak perempuan seperti bola bekel.Dalam hal ini, paman sangat menolak keras terhadap keinginan Maryamah ingin bertanding catur melawan laki-laki karena itu tidak pantas dilakukan oleh seorang perempuan. Hal lain dapat dilihat pada kutipan di bawah ini. Kutipan berikut "Di mana-mana tak ada perempuan bertanding catur melawan laki-laki!bentaknya berapi-api” (CDG/AH, 2016:103).

Perempuan dianggap tidak cocok mengerjakan pekerjaan yang memiliki nilai tinggi seperti pertandingan catur yang bergengsi di kampung tersebut. Dalam nover CDG menggambarkan bahwa ada sebuah tradisi yang menganggap perempuan adalah manusia setingkat lebih rendah dibanding laki-laki. Untuk itu perempuan hanya cocok dan pantas mengerjakan pekerjaan domestik yang tidak memiliki nilai ekonomi, seprti masak, mencuci pakaian, melayani suami dan lain sebagainya. 
c. Stereotip (pelabelan atau pandangan buruk terhadap perempuan)

Stereotip adalah pelabelan atau penandaan terhadap suatu kelompok tertentu. Stereotip tersebut sering menimbulkan konflik, sebab dengan memberikan label negatif pada kelompok tersebut akan merugikan kelompok tersebut. Salah satu jenis stereotip itu adalah yang bersumber dari pandangan jender.Banyak sekali ketidakadilan terhadap jenis kelamin tertentu, umumnya perempuan, yang bersumber dari penandaan (stereotip) yang dilekatkan kepada mereka.Dalam hal ini perempuan bersolek adalah dalam rangka memancing perhatian lawan jenisnya, maka setiap ada kasus kekerasan atau pelecehan seksual selalu dikaitkan dengan stereotip ini. Selain itu, pendidikan kaum perempuan selalu dinomorduakan karena peraturan pemerintah, keagamaan, kultur atau kebiasaan masyarakat. Di dalam novel $C D G$ karya Andrea Hirata terdapat stereotip gender pada tokoh utama perempuan, hal itu tampak pada kutipan berikut. "Tetap tak mungkin.Ketua panitia pertandingan tahun ini Modin. Dia itu orang islam yang keras. Mendengar perempuan main catur saja dia pasti tak setuju, apalagi mau melawan laki-laki” (CDG/AH, 2016:47).

Dari kutipan di atas terlihat bahwa laki-laki menolak keras apabila Maryamah ikut bertanding bermain catur melawan laki-laki. Modin yang merupakan ketua panitia pertandingan catur tahun ini adalah orang islam yang keras dengan segala peraturan-peraturan keagamaannya pasti akan terangterangan menolak keras niat Maryamah. Di dalam ajaran agama Islam, perempuan haram hukumnya melawan laki-laki.Itulah salah satu alasan Maryamah dilarang bertanding melawan lakilaki.

Maryamah ditentang Modin sebagai ketua panitia pertandingan catur itu, karena perempuan diharamkan bertanding catur melawan laki-laki.....Bagi laki-laki seorang perempuan tidak berhak bermain catur karena jika perempuan bermain catur, akan merontokkan wibawa pertandingan catur.

Cuplikan cerita di atas menggambarkan bahwa dilarangnya Enong untuk ikut bermain catur bukan karena ia tidak berkopentensi, namun karena ia adalah seorang perempuan. Perempuan dianggap tidak pantas ikut dalam permainan catur. Anggapan tidak pantas adalah sebuah stereotif atau pelabelan, karena mereka tidak melihat kemampuan namun melihat jenis kelamin.

d. Kekerasan (serangan baik fisik maupun psikis)

Kekerasan terhadap perempuan muncul karena perbedaan jender dan sosialisasi jender yang amat lama sehingga mengakibatkan kaum perempuan secara fisik lemah dan laki-laki umumnya lebih kuat maka hal itu tidak menimbulkan masalah sepanjang anggapan lemahnya perempuan tersebut mendorong laki-laki boleh dan seenaknya saja memukul perempuan. Tidak hanya itu, kekerasan yang dilakukan terhadap laki-laki juga mengakibatkan gangguan psikologis atau mental kaum perempuan. 


\section{1) Kekerasan Fisik}

Kekerasan fisik biasanya akan menimpah pada orang-orang yang dianggap lemah. Dalam hal ini adalah perempuan dan anak-anak, karena mereka dianggap tidak mampu memberikan perlawanan yang berarti. Perempuan adalah objek yang sering menerima kekerasan secara fisik baik dari orang yang tidak dikenal ataupun dari orang yang paling dekat dengannya seperti suami.

Tak seperti perkawinan ibu dan ketiga adiknya, Enong tidak beruntung. Kelakuan buruk suaminya telah tampak sejak awal perkawinan, namun ia bertahan. Seburuk apa pun ia diperlakukan, ia menganggap dirinya telah mengambil keputusan dan dia ingin menjaga perasaan ibunya. Namun, pertahanan Enong berakhir ketika suatu hari datang seorang perempuan yang mengaku sebagai istri Matarom.Perempuan itu dalam keadaan hamil.Ia tidak datang dengan marah-marah karena tahu apa yang telah terjadi bukan kesalahan Enong. Enong meminta maaf dan mengatakan bahwa sepanjang hidupnya ia tak pernah mengenal lelaki dan tak tahu banyak tentang Matarom. Enong mengakhiri perkawinannya secara menyedihkan.Ia minta diceraikan (CDG/AH, 2016:19).

Dalam kutipan di atas terlihat bahwa Maryamah atau yang sering dipanggil dengan sebutan Enong selalu mendapatkan perlakuan keras dari suaminya semenjak dia menikah dengan lelaki yang bernama Matarom.Semenjak kecil Maryamah sudah bekerja dan mendapatkan perlakuan yang buruk dari lelaki yang berniat jahat dan ingin mencelakakan dirinya.Hal itu dapat dilihat pada kutipan di bawah ini.

Ia hampir celaka karena diburu di hutan oleh sejumlah laki-laki karena mendulang timah. Kami miris mendengarnya ketakutan diperkosa dan dibunuh, lalu terjun ke hulu Sungai Linggang.Ia selamat karena tersangkut di akar bakau nun di muara. Maryamahmengatakan, sejak itu ia ketakutan setiap kali mendengar salak anjing (CDG/AH, 2016:252).

Dari kutipan di atas terlihat sejumlah laki-laki jahat mengejar Maryamah hingga di tengah hutan yang sepi.Maryamah melarikan diri karena takut diperkosa dan dibunuh secara sadis. Karena peristiwa tersebut Enong selalu ketakutan jika mendengar salak anjing. Kekerasan fisik sering terjadi pada wanita diluar rumah baik ditempat kerja maupun ketika perjalanan kembali kerumah.

\section{2) Kekerasan Nonfisik}

Di dalam novel $C D G$ karya Andrea Hirata terdapat kekerasan fisik terhadap tokoh utama perempuan.Pada saat itu, datang seorang perempuan yang sedang hamil yang mengaku istri Matarom.Enong meminta maaf kepada perempuan itu.Dengan keluguan Enong sebagai seorang perempuan, Matarom semena-mena telah membohongi Enong.Tak lama kemudian, Enong meminta Matarom untuk menceraikan dirinya.Kehidupan yang dialami Enong tak seindah yang dibayangkannya.Pernikahannya harus berujung pada perceraian atas perlakuan kejam dari suaminya. 
Miris kami mendengar Maryamah berkisah tentang nasibnya.Benar pendapat orang-orang tua Melayu, bahwa di dunia ini tak ada masalah sepelik soal rumah tangga.Kasihan dia, sungguh berat cobaan hidupnya.Nada bicaranya jelas mengesankan bahwa Matarom dan catur telah menjadi biang keladi kesusahannya. Namun, ia memang perempuan yang istimewa. "Kalau aku susah," katanya dengan sorot mata yang lucu, "cukuplah kutangisi semalam.Semalam suntuk.Esoknya, aku tak mau menangis. Aku bangun dan tegak kembali! (CDG/AH, 2016:45).

Dari kutipan di atas terlihat Maryamah sedang menceritakan tentang nasibnya yang kelam dan menyedihkan.Rumah tangga Maryamah yang hancur karena kebohongan dan kekerasan fisik yang dia alami selama perkawinannya.Matarom adalah juara catur yang handal dan sampai sekarang belum ada yang mampu mengalahkannya. Maka dari itu, ia menjadi lelaki yang semenamena terhadap perempuan karena kekuasaannya itu. Kesemena menahan Matarom karena ia menganggap Enong adalah manusia lemah yang dengan mudah akan menerima penindasannya. Kelemahan Enong karena ia adalah seorang istri dan seorang perempuan. Perempuan dianggap tak mampu memberikan perlawanan untuk itu perempuan sering dijadikan objek tidak kekerasan yang dilakukan oleh orang terdekat.

Kutipan 25

Baginya, catur pastilah representasi Matarom dan seluruh kejadian mengiriskan yang telah menimpanya. Di depan papan catur itu ia pasti merasa sedang berhadapan dengan suaminya. Ia tak berani menyentuh buah-buah catur itu. Kemudian, kulihat matanya berkaca-kaca.Ia menunduk, tafakur. Air matanya berjatuhan, aku iba melihat bahunya yang merosot (CDG/AH, 2016:57).

Karena sering menerima intimidasi akhirnya mental Enong pun tergoyahkan. Enong merasa tertekan secara psikologis ketika ia berhadapan dengan Matarom. Enong merasa bahwa yang dihadapannya sekarang bukanlah lawan main caturnya namun yang dihapannya sekarang adalah suaminya. Untuk itu ia merasa takut dan tertekan, mengingat bagaimana perlakuan Matarom terhadapnya ketika ia masih menjadi istri Matarom.

\section{e. Beban Kerja terhadap Perempuan dalam Novel $C D G$ Karya Andrea Hirata}

Adanya anggapan bahwa kaum perempuan memiliki sifat memelihara dan rajin, serta tidak cocok untuk menjadi kepala rumah tangga, berakibat bahwa semua pekerjaan domestik rumah tangga menjadi tanggungjawab kaum perempuan. Di lain pihak, kaum lelaki tidak diwajibkan secara kultural untuk menekuni berbagai jenis pekerjaan domestik itu. Kesemuaannya itu telah memperkuat pelanggengan secara kultural dan struktural beban kerja kaum perempuan.

Oleh karenanya rumah tangga juga menjadi tempat kritis dalam mensosialisasikan ketidakadilan gender. Dengan demikian dapat disimpulkan bahwa manifestasi ketidakadilan gender ini telah mengakar mulai dalam keyakinan di masing-masing orang, keluarga hingga pada tingkat negara yang bersifat global. Di dalam novel CDGkarya Andrea Hirata terdapat beban kerja terhadap 
tokoh utama perempuan, hal itu tampak pada kutipan berikut."Enong bekerja keras menjadi pendulang timah sejak usianya baru 14 tahun.Ia berusaha sedapat-dapatnya memenuhi apa yang diperlukan ketiga adiknya dari seorang ayah" (CDG/AH, 2016:11).

Pendulang timah adalah pekerjaan seorang laki-laki karena berat dan perempuan tidak mampu melakukan pekerjaan itu.Akan tetapi, Enong mampu melakukannya demi tekadnya menghidupi keluarganya. Enong mampu mengerjakan pekerjaan yang seharusnya dilakukan seorang laki-laki bukan karena ia suka, namun karena desakan kebutuhan ekonomi yang harus ia tanggung sendiri. Ia berperan sebagai seorang ayah bagi adik-adiknya, dan berperan sebagai seorang teman bagi ibunya. Beban kerja yang ganda ini Enong lakoni dengan sekuat tenaga agar keluarganya mampu bangkit sebagaimana keluarga normal yang lainnya walupun tanpa seorang Ayah.

Lihat kembali cuplikan cerita berikut "Sejak usianya 14 tahun, perempuan malang itu telah memanggul beban yang tak terbayangkan beratnya. Kupandangi lengannya yang besar dan kasar, jemarinya yang hitam, berkerak, dan kaku, seperti bilah-bilah besi karena bertahun-tahun mendulang timah" (CDG/AH, 2016:57).Dari kutipan di atas tampak Enong sangat bekerja keras menjadi tulang punggung keluarganya menggantikan almarhum ayahnya.Enong mengerjakan pekerjaan berat yang seharusnya dikerjakan oleh laki-laki. Pekerjaannya sebagai pendulang timah yang selama ini ia jalani untuk memenuhi kebutuhan keluarganya.

\section{SIMPULAN}

Hubungan jender dalam novel $C D G$ karya Andrea Hirata terdiri dari perbedaan sifat antara laki-laki dan perempuan dalam peran, fungsi, hak, tanggung jawab, dan perilaku yang dibentuk oleh tata nilai sosial, budaya, dan adat istiadat dari kelompok masyarakat setempat. Seperti perempuan itu dikenal lemah lembut, cantik, emosional, dan keibuan.Sementara laki-laki dianggap kuat, rasional, jantan, dan perkasa. Karena sifat-sifat bawahan yang dilekatkan pada laki-laki dan perempuan maka berpengaruh pada peran sosial di masyarakat, seperti laki-laki harus mengerjakan pekerjaan yang berat dan kasar sedangkan perempuan mengerjakan pekerjaan domestik. Nmaun karena tuntutan ekonomi akhirnya perempuan juga terpaksa harus mengerjakan pekerjaan yang identik dengan sifat maskulinitas.

Bentuk ketidakadilan jender dalam novel $C D G$ karya Andrea Hirata meliputi: (a) marginalisasi terhadap perempuan: marginalisasi dalam novel ini terjadi di tempat pekerjaan, rumah tangga, masyarakat dan kultur, bahkan negara yang menentang perempuan untuk bekerja dan pertentangan hak terhadap kaum perempuan sehingga memiskinkan para kaum perempuan; (b) subordinasi terhadap perempuan: subordinasi yang terdapat dalam novel ini menjadikan perempuan menjadi seorang yang tidak penting dan selalu dinomorduakan terutama dalam hal pendidikan 
sehingga perempuan tidak memiliki hak yang sama seperti kaum lelaki; (c) stereotip terhadap perempuan: dalam novel ini steriotip dapat dilihat dari pelabelan atau penandaan terhadap suatu kelompok tertentu bahwa perempuan hanya bisa mengerjakan tugas perempuan, bahkan tidak layak melakukan pekerjaan atau hal-hal seperti laki-laki; (d) kekerasan terhadap perempuan: kekerasan dalam novel ini muncul karena perbedaan gender sehingga mengakibatkan kaum perempuan secara fisik lemah daripada kaum laki-laki, maka dari itu perempuan sering mendapat kekerasan baik secara fisik maupun mental; dan (e) beban kerja: beban kerja yang terdapat pada novel ini adanya anggapan bahwa perempuan tidak cocok menjadi kepala rumah tangga sehingga semua pekerjaan domestik dalam rumah tangga menjadi tanggungjawab kaum perempuan.

\section{DAFTAR RUJUKAN}

Ahmadi, Abu. 2009. Psokologi Sosial. Jakarta: PT Rineka Cipta.

Fakih, Mansour. 1999. Analisis Jender dan Transformasi Sosial. Yogyakarta: Pustaka Pelajar

Hirata, Andrea. 2016. Cinta di Dalam Gelas. Yogyakarta: PT Bentang Pustaka.

Katjasungkana, Nursyahbani, dkk. 2001. Potret Perempuan. Yogyakarta: Pustaka Pelajar.

Nurgiyantoro, Burhan. 2012. Teori Pengkajian Fiksi. Yogyakarta: Gadjah Mada University Press.

Pertiwi Manda, Endang. 2017. Perspektif Gender dalam Karya Sastra.https://blog.igi.or.id/perspektif-gender-dalam-karya-sastra.html. Diakses tanggal $\underline{11 / 04 / 2018 \text { Pukul } 13.44}$

Rauf Mayang, Abdul. 2011. Faktor-Faktor Ketidakadilan Gender.http://jamal$\underline{\text { alfath.blogspot.co.id/search?q=faktor+faktor+ketidakadilan+gender. }}$ Diakses tanggal $\underline{11 / 04 / 2018 \text { Pukul } 13.53}$

Sugihastuti dan Suharto. 2005. Kritik Sastra Feminis. Yogyakarta: Pustaka Pelajar.

WS, Indrawan. 2014. Kamus Lengkap Bahasa Indonesia.Jombang: Lintas Media

Yuda, Endra. 2012. Contoh Relasi Gender dan Seks.https://feelinbali.blogspot.co.id/2012/12/contoh-relasi-gender-dan-seks.html. Diakses tanggal 11/04/2018 Pukul 12.05

Zaidan, Abdul Rozak, Anita K. dan Hani'ah. 2007. Kamus Istilah Sastra. Jakarta: Balai 